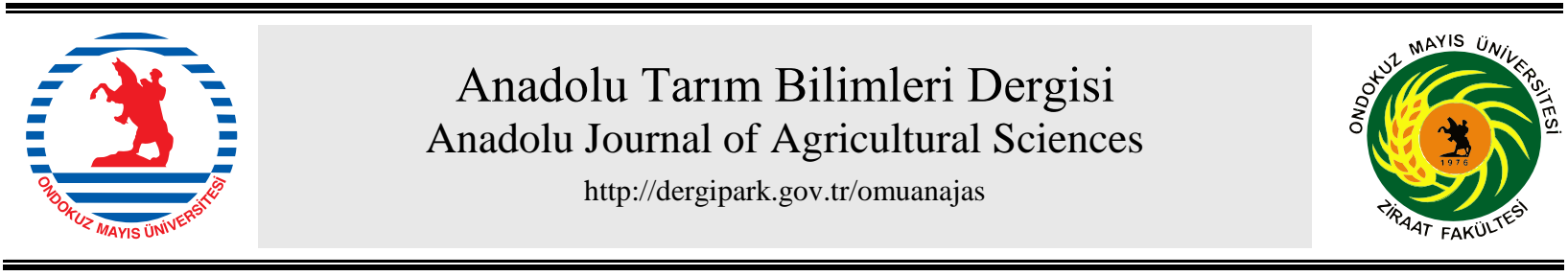

\title{
Araştırma/Research
}

Anadolu Tarım Bilim. Derg./Anadolu J Agr Sci, 35 (2020) ISSN: 1308-8750 (Print) 1308-8769 (Online) doi: 10.7161/omuanajas.673290

\section{Organik atık uygulamalarının asit, nötr ve alkali toprakların üreaz enzim aktiviteleri üzerine etkisi}

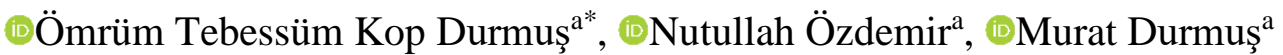 \\ ${ }^{a}$ Ondokuz Mayıs Üniversitesi, Ziraat Fakültesi, Toprak Bilimi ve Bitki Besleme Bölümü, Samsun, Türkiye
}

*Sorumlu yazar/corresponding author: tebessum.kopdurmus@omu.edu.tr

Geliş/Received 10/01/2020 Kabul/Accepted 21/04/2020

\begin{abstract}
ÖZET
Bu çalışma organik atıkların farklı $\mathrm{pH}$ değerlerindeki topraklara uygulanması sonucunda topraktaki üreaz enzim aktivitesindeki değişimleri ve üreaz enzim aktivitesi ile toprağın bazı özellikleri arasındaki ilişkileri belirlemek amacıyla yapılmıştır. Deneme serada kontrollü koşullarda saksıda ve üç farklı $\mathrm{pH}$ (asit, nötr, alkali) değerine sahip toprakta üç tekerrürlü olarak yürütülmüştür. Organik düzenleyici olarak kullanılan tütün işleme atı̆̆1 (TA), çeltik kavuzu kompostu (ÇEK) ve çöp kompostu (ÇK); \%0.0, \%2.5, \%5.0 ve \%7.5 şeklinde 4 doz olarak uygulanmıştır. Bir aylık inkübasyon döneminden sonra hazırlanan saksılarda bitki yetiştirilmiştir. Deneme sonrasında saksılardan alınan toprak örneklerinde üreaz enzim aktivitesi belirlenmiş ve asit pH'ya sahip toprakta en yüksek enzim aktivitesi \%5.0 TA uygulaması sonrasında, nötr $\mathrm{pH}$ 'ya sahip toprakta \%7.5 ÇK uygulaması sonrasında, alkali pH'ya sahip toprakta ise \%7.5 TA uygulaması sonrasında belirlenmiştir. Ayrıca deneme sonrasında topraktaki üreaz enzim aktivitesi ile toprağın $\mathrm{pH}, \mathrm{EC}$, organik madde ve kireç içerikleri ile istatistiksel açıdan önemli ilişkiler belirlenmiştir.
\end{abstract}

Effect of Organic Waste Applications on Soil Urease Enzyme Activities of Acid, Neutral and Alkaline Soils

\section{ABSTRACT}

This study was carried out to determine the changes in soil urease enzyme activity and the relationship between its and some properties of soil as a result of application of organic wastes to soils having different $\mathrm{pH}$. The experiment was conducted as a pot experiment under controlled conditions in a greenhouse and 3 repeats with soils having 3 different $\mathrm{pH}$ (acid, neutral, alkaline) values. As organic materials; tobacco processing waste (TW), rice husk compost (RHC) and municipal solid waste (MW) were used in four different rates $(0.0,2.5,5.0$ and $7.5 \%)$. After a one-month incubation period, the plant was grown in the prepared pots. At the end of the experiment, urease enzyme activity was determined in soil samples taken from pots and the highest enzyme activity was determined in acid soil with $5.0 \%$ TW application, in neutral soil with 7.5\% MW application and in alkaline soil with 7.5\%TW application. Moreover, statistically significant relationships were found between soil urease enzyme activity and soil $\mathrm{pH}, \mathrm{EC}$, soil organic matter, and lime content.
Anahtar Sözcükler:

Toprak

Üreaz Enzimi

Organik Madde

Toprak pH's1
Keywords:

Soil

Urease Enzyme

Organic Matter

Soil pH

(C) OMU ANAJAS 2020 


\section{Giriş}

Doğal kaynakların ve üretkenliğin sürdürülebilirliği konusundaki endişelerin artması, toprak kaynaklarını koruyan ve geliştiren yönetim stratejilerinin geliştirilmesini zorunlu kılmaktadır. Konu, toprağın kritik bir bileşeni olan topraktaki organik madde miktarının korunması ile doğrudan ilgilidir. Korunma ve değişim zaman dilimi içerisindeki kültivasyon, bitki münavebesi, atık yönetimi ve gübreleme uygulamaları ile ilişkilidir (Campbell ve ark., 1992). Organik madde, ayrışma ürünleri ile besin elementleri sağlamanın yanında biyolojik çeşitliliği ve aktiviteyi, toprak strüktürünü, havalanmayı, toprak su içeriğini, toprak sıcaklığını, bitki gelişimini, toprak oluşumunu ve erozyona karşı direnci olumlu yönde etkilemektedir (Ferreras ve ark., 2006). Yeşil aksamlı sebze bitkileri, ideal bir büyüme ve bu büyümenin sonucunda optimum verim için yeterli ve daimi bir azot $(\mathrm{N})$ kaynağına ihtiyaç duyarlar (Chang ve ark., 2007). Günümüzde geleneksel tarım sistemlerinde kimyasal gübre kullanımı oldukça yaygındır. $\mathrm{Bu}$ kimyasal gübreler içerisinde azotlu gübreler hem dünyada hem de ülkemizde en çok kullanılan aynı zamanda bitkisel üretimde özel bir yeri bulunan gübrelerdir. (Şahin 2016). 2013 yılında dünya genelinde kullanılan azotlu gübreler toplam NPK gübrelerinin yaklaşık olarak yarısını kapsamaktadır (FAO, 2016). Türkiye'de azotlu gübre kullanımında üre gübresi amonyum nitrat gübresinden sonra ikinci sırada gelmekte ve üreticiler genellikle tarla bitkileri yetiştiriciliğinde üst gübreleme olarak üreyi tercih etmektedirler (Çolakoğlu ve ark., 2004; Eraslan ve ark., 2010). Üre toprakta bitkiler tarafindan direkt olarak alınabilir yapıda olmadığı için ürenin bitki tarafından alınabilmesi için hidrolize olması gerekmektedir. Ürenin kendi başına hidrolize olması çok uzun zaman almaktadır, işte burada üreaz enzimi devreye girmekte ve önemi anlaşılmaktadır. Üreaz enzimi, ürenin hidrolizini normal reaksiyonlara göre 1014 kat daha hızlı katalize etmektedir. Üreaz yapısında nikel bulundurmakta (Sırko ve Brodzık 2000) ve üreyi hidrolize ederek amonyak ve karbondioksitin açığa çıkmasını sağlamaktadır (Tanaka ve ark., 2004).

Herhangi bir değișiklik olmadan reaksiyonları katalize eden enzimlerin aktiviteleri organik madde içerikleri ile yakından ilişkili olup topraktaki besin döngüsünün ayrılmaz bir parçasını oluştururlar. Enzimler toprak ekolojik sisteminin ve çevresel değişikliklerin hassas göstergeleridir (Marinari ve ark., 2006; Bhavya ve ark., 2017). Mikroorganizmalar tarımda kullanılan organik materyallerin ayrışma ve sentezinde önemli rol oynamakta ve etkinlikleri yönünden toprak özellikleri, tarımsal pratikler ve çevresel koşullardan önemli ölçüde etkilenmektedirler (Carney ve Matson, 2005; Özdemir ve ark., 2018). Aslında, toplam karbon konsantrasyonu mikrobiyal biyokütle ve enzim aktiviteleri üzerinde toprak yönetimi uygulamalarına oranla daha etkilidir (Bergstrom ve ark., 1998; Aon ve Colaneri, 2001).

Baran ve ark., (1995), tütün işleme atığı, üzüm cibresi ve atık mantar kompostunu, Sawicka ve ark., (2004), tütün işleme atığı ve atık çamurunu, Kurt (2016), biyokömür ve vermikompostu, Doğan ve ark., (2018), zeytin karasuyu, 1sıl işlem görmüş solucan gübresi ve çiftlik gübresini, toprağa ilave ederek toprağın biyolojik özellikleri ve enzim aktivitesinde meydana gelen değişimleri incelemişler ve uygulamaların toprakların biyolojik özellikleri üzerine olumlu etkilerinin olduğunu bildirmiş̧lerdir. Toprak kalitesinin bir bileşeni olan mikroorganizmalar (Hackl ve ark., 2004) toprak organik maddesini ayrıştırarak besin döngüsüne yaptığı etki ile verimlilikte önemli bir rol oynarlar (Kızlkaya ve Hepşen, 2004). Kompleks toprak sisteminde toprak muhafaza ve verimliliğine ilișkin hususların değerlendirilmesinde biyolojik unsurların dikkate alınması önem taşımaktadır. Liu ve ark. (2002), mısırpirinç rotasyon sistemini esas alarak yürüttükleri bir araştırmada farklı ekosistemlerde bulunan topraklarda enzim aktivitesi ile bazı toprak kalite parametrelerinde meydana gelen değişimleri irdelemişlerdir. Organik gübreler ile azot (N)'un kompoze edilerek yürütüldüğü çalışmada tarım toprağının kalite indeksinin mısır ürünü ile önemli derecede ilişkili olduğu $(p<0,05)$, tarım toprağının kalitesinin değerlendirilmesinde indikatör olarak toprak enzim aktivitelerinin kullanılmasının uygun olduğu belirlenmiştir.

Zimmermann ve Frey (2002), asidik karakterli toprakta solunum ve mikrobiyal aktivite üzerine ağaç külünün etkisini belirlemek üzere mikrobiyal biyomas karbonu, bazal solunum, toprak solunumu ve enzim aktiviteleri gibi çeşitli mikrobiyal değerleri esas alarak yürüttükleri çalışma sonucunda ağaç külü eklentili topraktaki mikrobiyal aktivitenin arttığını, bu artışın da toprağa eklenen besin miktarı, pH'daki artış ve ağaç külü ilavesinden sonraki ilk günde toplam karbon ve azot içeriklerinin düşmesi şeklinde ilerleyen organik madde mineralizasyonunun artışı ile ilişkili olduğunu belirtmişlerdir. Türkmen ve ark., (2013) ise mera 1slah çalışmalarının toprakta bazı biyolojik özellikler üzerine etkilerini belirlemek üzere yürüttükleri çalışmada mera ıslah uygulamalarının organik $\mathrm{C}, \mathrm{C}: \mathrm{N}$ oranı, mikroorganizma sayıs1, katalaz ve üreaz enzim aktivitelerinde istatistiksel olarak önemli $(\mathrm{P}<0.01)$ farklılıklar oluşturduğunu saptamışlardır.

Antil ve ark., (2006), farklı organik materyal, substrat konsantrasyonu ve toprak neminin üreaz enzim aktivitesi üzerine etkilerini araştırmışlardır. Çalışma sonunda organik materyal uygulamalarının toprakta üreaz enzim aktivitesini artırdığını belirtmişlerdir.

Chang ve ark., (2007), yapmış oldukları çalışmada toprağa 4 farklı kompost uygulayarak topraktaki enzim aktivitesindeki değişimleri araştırmışlardır ve kompost uygulamasının toprakta üreaz enzim aktivitesini artırdığını ayrıca toprak organik maddesi ile üreaz enzim 
aktivitesi arasında doğrusal bir korelasyon olduğunu bildirmişlerdir.

Doğal kaynakların sürdürülebilir kullanımına yönelik planlama, yönetim ve girdi uygulamalarına bağlı bozulma ve farkl11ıkların belirlenmesinde enzimatik faaliyetlerdeki değişim oldukça önemlidir (Aon ve ark., 2001). Makro besin elementlerinden olan azot tarımsal üretimde en çok ihtiyaç duyulan besin elementi olup noksanlığında ise ürün ve kalite eksikliği meydana gelmektedir (Mengel, 1991). Azotlu gübreler içerisinde en çok azot ihtiva eden ürenin (\% $46 \mathrm{~N})$ doğrudan toprağa uygulandığında bitki tarafindan alınabilmesi topraktaki üreaz enziminin aktivitesine bağlıdır. Üreaz enzimi canlı hücreler tarafindan sentezlenen bir enzim olmasından dolayı üre gübresinin uygulandığı toprağın mikroorganizma aktivitesinin yüksek olması beklenmektedir. $\mathrm{Bu}$ nedenle tarımsal üretimde üre gübresinin kullanımında organik madde ilavesinin göz ardı edilmemesi gerektiği düşünülmektedir. Ülkemiz topraklarının organik madde içeriğinin düşük seviyede olmasından dolayı üre uygulamalarında kullanılan gübre tam olarak etkili olmayabilir. Bu durum hem ekonomik açıdan hem de çevre sağlığı açısından tehdit oluşturabilmektedir. Tüm enzimler gibi üreaz enzimi de toprakta aktivite gösterebilmesi için optimum bir $\mathrm{pH}$ aralığına ihtiyaç duymaktadır. Bu nedenle bu çalışma üreaz enzim aktivitesi üzerine; toprak $\mathrm{pH}$ 'sı ve topraklara uygulanan farklı organik materyallerin etkilerini belirlemek üzere yürütülmüştür.

\section{Materyal ve Yöntem}

\subsection{Sera Denemesi}

Sera denemesinde üç farklı $\mathrm{pH}$ değerine sahip toprak örnekleri kullanılmıştır. Nötr, asit ve alkalin reaksiyonlu topraklar Samsun ilinin Bafra ilçesine bağlı Tepecik ve Çetinkaya köyleri ile Samsun Ondokuz Mayıs Üniversitesi Kurupelit Kampüs alanında bulunan Ziraat Fakültesi deneme topraklarının yüzey $(0-20 \mathrm{~cm})$ katmanından alınmıştır. Organik materyal olarak ise tütün işleme atığı (TA), çeltik kavuzu kompostu (ÇEK) ve çöp kompostu (ÇK) kullanılmıştır. TA Ballıca Sigara Fabrikasından, ÇEK OMÜ Ziraat Fakültesi Toprak Bilimi ve Bitki Besleme Bölümünden ve ÇK ise İstanbul Büyükşehir Belediyesi Kemerburgaz Kompost ve Geri Kazanım Tesisinden temin edilmiştir.

Sera denemesi güz döneminde OMÜ Ziraat Fakültesi Toprak Bilimi ve Bitki Besleme Bölümü araştırma ve deneme seralarında kontrollü koşullarda ve $25{ }^{0} \mathrm{C}$ sıcaklık şartlarında 3 tekerrürlü olarak yürütülmüştür. Toprak örnekleri 4 mm'lik elekten geçirildikten sonra her bir plastik saksıya firın kuru ağırlık esasına göre $4.5 \mathrm{~kg}$ toprak konulmuştur. Plastik saksılara organik düzenleyiciler $\% 0.0, \% 2.5, \% 5.0$ ve $\% 7.5$ olacak şekilde 4 doz olarak uygulanmış ve saksıdaki topraklar tarla kapasitesine gelinceye kadar su ilave edilmiştir. Hazırlanan saksılar 4 hafta süre ile inkübasyona bırakılmışlardır. İnkübasyon periyodunda topraklar 2 günde bir tartılarak kaybolan su topraklara ilave edilmiştir. İnkübasyon periyodunun sonunda her saksıya 1 adet marul fidesi (Lactuca sativa var. Crispa) dikilerek deneme yürütülmüş ve inkübasyon periyodu da dahil olmak üzere toplam 159 gün sürmüştür. Deneme süresince saksılara sulamanın dışında herhangi bir kültürel uygulama yapılmamıştır.

\subsection{Toprak Analizleri}

Üreaz enzim aktivitesinin belirlenmesi amaciyla deneme sonunda saksılardan taze toprak örnekleri (rizosfer bölgesi dışından) alınarak 2 mm'lik elekten geçirilmiş ve ağzı kilitli poşetlere konularak analiz için buzdolabında muhafaza edilmiştir. Üreaz enzim analizi dışında kalan diğer analizler için yine saksılardan toprak örnekleri (rizosfer bölgesi dışından) alınmış, gölgede kurutularak 2 mm'lik elekten geçirilmiş ve analize hazır hale getirilmiştir. Elde edilen tüm sonuçlar firın kuru toprak üzerinden değerlendirilmiştir. Denemede kullanılan toprak örneklerinin tekstür analizi Bouyoucas Hidrometre yöntemine göre, organik madde içeriği Walkley-Black yöntemine göre, $\mathrm{pH}$ değerleri 1:1 topraksu süspansiyonunda cam elektrotlu $\mathrm{pH}$ metre ile, toplam azot Kjeldahl yöntemine göre belirlenmiştir (Rowell, 1996). Toprak örneklerinin üreaz aktivitesi Hoffmann ve Teicher (1961) tarafindan bildirildiği şekilde belirlenmiştir. $\mathrm{Bu}$ amaçla; toprak örnekleri üzerine sitrat tampon $(\mathrm{pH}=6.7)$ ve substrat üre çözeltisi ilave edilmiş, 1 saat süre ile $37{ }^{\circ} \mathrm{C}$ 'de inkübasyona bırakılmıştır. İnkübasyon sonucunda açığa çıkan amonyum, sodyum fenalat çözeltisi ile renklendirilerek 578 nm'de spektrofotometrede belirlenmiş, elde edilen sonuçlar mg $\mathrm{N} 100 \mathrm{~g}^{-1}$ kuru toprak 1 saat $^{-1} 37{ }^{\circ} \mathrm{C}$ cinsinden ifade edilmiştir. Organik atık ve kompostların toplam N kapsamı Kjeldahl yöntemi ile, organik karbon kuru yakma yöntemi ile, C:N oranı ise karbon ve azot sonuçlarından hesaplama ile belirlenmiştir (Kacar ve İnal, 2008). Çalışmada elde edilen bulgulara ait varyans analizleri ve Duncan testleri SPSS paket programında yapılmış, sonuçlar Düzgüneş (1987) tarafindan bildirildiği şekilde değerlendirilmiştir.

\section{Bulgular ve Tartışma}

\subsection{Denemede kullanılan topraklar ve organik materyallerin özellikleri}

Sera denemesinde kullanılan Tepecik yöresinden alınan toprak örneğinin asit reaksiyonlu, killi tın bünyeli, Çetinkaya yöresine ait toprak örneğinin alkalin reaksiyonlu tın bünyeli ve Kampüs alanı toprağının ise nötr reaksiyonlu kumlu kil bünyeli olduğu belirlenmiştir (Çizelge 1). 
Çizelge 1. Deneme topraklarının bazı özellikleri

Table 1. Some properties of experiment soils

\begin{tabular}{cccccc}
\hline Toprak Ad1 & O.M. (\%) & pH & Kum (\%) & Silt (\%) & Kil (\%) \\
\hline Tepecik & 2.40 & 5.60 & 26.54 & 34.06 & 39.40 \\
Kampüs & 1.13 & 7.00 & 34.15 & 25.63 & 40.22 \\
Çetinkaya & 1.31 & 8.33 & 45.64 & 39.41 & 14.95 \\
Tepecik & 2.40 & 5.60 & 26.54 & 34.06 & 39.40 \\
\hline
\end{tabular}

Tütün işleme atığg kuru ağırlık esasına göre \%38.40 organik C (\%66.21 OM) ve \%1.97 N ihtiva etmekte olup C:N oranı 19.49 dur. Çeltik kavuzu kompostu kuru ağırlık esasına göre \%9.91 organik C (\%19.82 OM) ve
\%0.88 N ihtiva etmekte olup C:N oranı 11.26 dır. Çöp kompostu kuru ağırlık esasına göre \%17.86 organik C (\%35.71 OM) ve \%1.55 N ihtiva etmekte olup C: $\mathrm{N}$ oranı 11.52 dir (Çizelge 2).

Çizelge 2. Organik materyallerin bazı özellikleri

Table 2. Some properties of organic materials

\begin{tabular}{cccc}
\hline Organik Materyal & O.C. (\%) & Toplam N (\%) & C:N \\
\hline Tütün İşleme Atığ1 & 38.40 & 1.97 & 19.49 \\
Çeltik Kavuzu Kompostu & 9.91 & 0.88 & 11.26 \\
Çöp kompostu & 17.86 & 1.55 & 11.52 \\
\hline
\end{tabular}

\section{2 Üreaz enzim aktivitesi}

Asit, nötr ve alkalin reaksiyona sahip toprak örneklerine 4 farklı dozda tütün işleme atığı, çöp ve çeltik kavuzu kompostu ilave edilerek yetiştirilen marul bitkisinin hasadından sonra belirlenen üreaz enzim aktivitesi değerlerindeki değişim Şekil 1., 2., 3.' de ve bu değerlere ilişkin varyans analiz sonuçları ise Çizelge 3.'de verilmiştir. Bazı toprak özellikleri ile üreaz aktivitesi arasındaki ilişkiler ise Çizelge 4.' de sunulmuștur. $\mathrm{Bu}$ verilerin irdelenmesinden de anlaşılacağı üzere üreaz enzim aktivitesi toprak tipi, uygulanan organik materyal ve organik materyalin dozlarına bağlı olarak değişkenlik göstermiştir (Çizelge 3, Şekil 1., 2., ve 3.). Üreaz, toprakta mikroorganizmalar tarafindan sentezlenen ekstraselülar bir enzimdir ve azot dönüşümünde görev almaktadır. $\mathrm{Bu}$ enzim toprakta ürenin hidrolizini gerçekleştirmekte ve aktivite sonunda karbondioksit ile amonyak açığa çıkmaktadır (Bremner ve Mulvaney 1978). Üreaz enzimi büyük ölçüde toprak mikroorganizmaları tarafından sentezlenmekte; ancak aktivite göstermesi için sentezlendiği mikroorganizmaya ihtiyaç duymamaktadır (Bandick ve Dick, 1999; Karaca ve ark., 2002). Üreaz enzimi özellikle organik azotlu bileşikler içerisinde önemli bir paya sahip olan ürenin veya kimyasal yollarla topraklara ilave edilen üre gübresindeki üre azotunun hidrolizini sağlamakta ve toprak verimliliğine önemli katkılar sağlamaktadır (Dick ve Tabatabai, 1992).

Çizelge 3. Varyans analiz sonuçları

Table 3. Variance analysis results

\begin{tabular}{cccccc}
\hline Kaynaklar & $\begin{array}{c}\text { Kareler } \\
\text { Toplamı }\end{array}$ & $\begin{array}{c}\text { Serbestlik } \\
\text { Derecesi }\end{array}$ & $\begin{array}{c}\text { Kareler } \\
\text { Ortalamas }\end{array}$ & $\begin{array}{c}F \\
\text { Değeri }\end{array}$ & $\begin{array}{c}\text { Önemlilik } \\
\text { Düzeyi }\end{array}$ \\
\hline Toprak & 0.161 & 2 & 0.081 & 11.465 & 0.000 \\
Atık & 0.99 & 2 & 0.495 & 70.325 & 0.000 \\
Doz & 0.464 & 3 & 0.155 & 21.988 & 0.000 \\
Toprak * Atık & 0.137 & 4 & 0.034 & 4.868 & 0.002 \\
Toprak * Doz & 0.518 & 6 & 0.086 & 12.272 & 0.000 \\
Atık * Doz & 0.47 & 6 & 0.078 & 11.125 & 0.000 \\
Toprak * Attk * Doz & 0.814 & 12 & 0.068 & 9.639 & 0.000 \\
Hata & 0.507 & 72 & 0.007 & & \\
Toplam & 11.996 & 108 & & & \\
\hline
\end{tabular}

Çalışma sonunda elde edilen verilere göre, asit $\mathrm{pH}$ değerine sahip Tepecik toprağında üreaz enzim aktivitesi 0.11-0.85 mg N $100 \mathrm{gr}^{-1}$ fkt $1 \mathrm{~h}^{-1} 37{ }^{\circ} \mathrm{C}$ arasinda değişkenlik göstermektedir (Şekil 1). Asit reaksiyonlu toprağa uygulanan tütün atığı, çöp kompostu ve çeltik kavuzu kompostu toprakta üreaz enzim aktivitesini artırmıştır. Düzenleyiciler arasında topraktaki üreaz enzim aktivitesinin yükselmesine en fazla tütün atığının 
etki ettiği görülmektedir. Asit reaksiyonlu Tepecik toprağına yapılan tüm uygulamalar değerlendirildiğinde ise en yüksek üreaz enzim aktivitesi \%5.0 TA ve \%2.5 TA uygulaması sonrasında belirlenmiş ve bu iki uygulama istatistiksel açıdan benzer bulunmuştur. ÇEK uygulamasının hiçbir dozunun bu toprakta üreaz enzim aktivitesi üzerine herhangi bir etkisinin olmadığı belirlenmiştir. Ayrıca \% 7.5 TA ve \%2.5 ÇK uygulaması da benzer şekilde herhangi bir etki göstermemiştir. Arcak ve ark., (1997) yaptıkları bir çalışmada toprağa farklı oranda ince ve kaba çay atığı, kaba çay atı̆g 1 ile \%1.0 oranında hayvan gübresinin karıştırılması ile kompost ve katkı maddeleri ile karıştırılarak elde edilen zenginleştirilmiş kompostu uygulayarak farklı inkübasyon sürelerinde topraktaki enzim aktivitelerinin değişimini araştırmışlardır. Çalışma sonunda, uygulama yapılmış topraklardaki üreaz enzim aktivitesindeki artışın kontrol toprağındaki üreaz enzim aktivitesine göre istatistiksel açıdan önemli olduğu ve çay atığı uygulanan toprakta üreaz enzim aktivitesinin 1 . 2. ve 3. haftalarda yüksek çıktığı, 4 . haftada azaldığı belirtilmiştir.

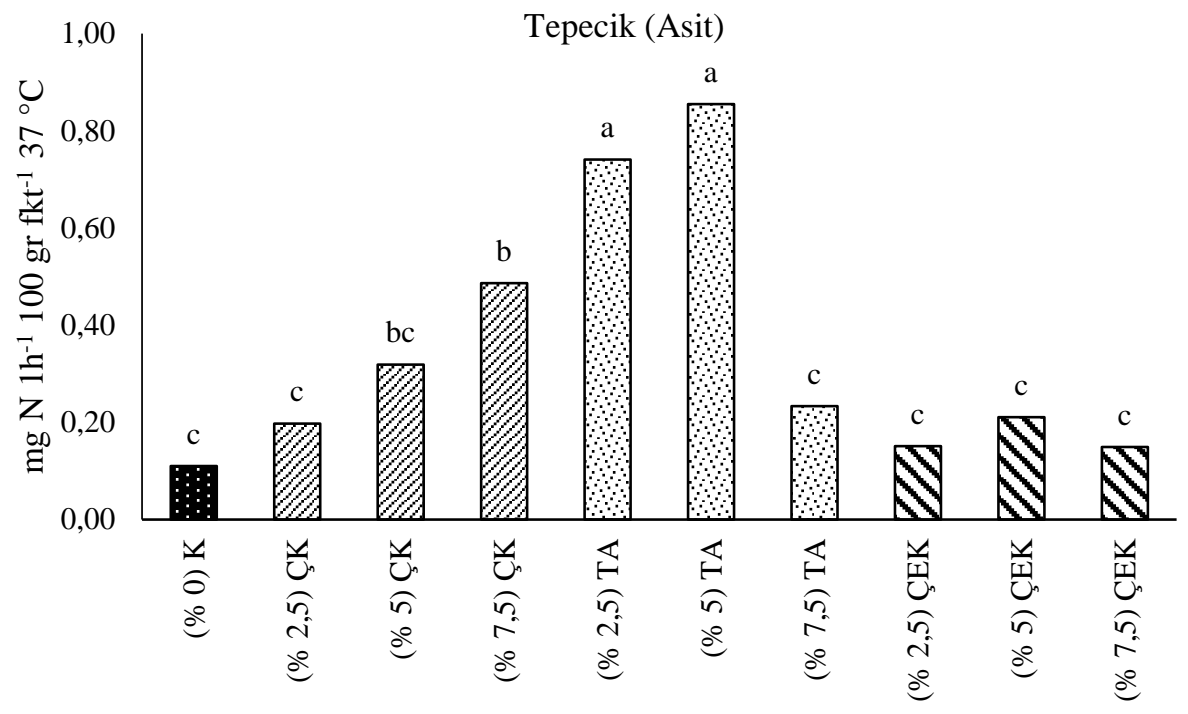

Şekil 1. Organik atık ve kompost uygulamalarının asit toprakta üreaz enzim aktivitesine etkisi

Figure 1. Effect of organic waste and compost applications on urease enzyme activity in acid soil

pH değeri 7.0 olan kampüs toprağına yapılan uygulamalar sonrasinda topraktaki üreaz enzim aktivitesi 0.16-0.42 mg N 100 gr $^{-1}$ fkt $1 \mathrm{~h}^{-1} 37{ }^{\circ} \mathrm{C}$ arasinda değişkenlik göstermektedir (Şekil 2). Çeltik kavuzu kompostunun her üç dozu ve çöp kompostunun \%2.5 dozu toprağa uygulandığında topraktaki üreaz enzim aktivitesinin kontrol toprağına göre azaldığı belirlenmiştir, ancak bu fark istatistiksel açıdan önemsiz bulunmuştur. Bunun haricinde yapılan diğer uygulamaların toprakta üreaz enzim aktivitesini arttığı belirlenmiş ancak bu artışlar arasında istatistiksel açıdan herhangi bir fark bulunmamıştır.
Nötr reaksiyonlu toprakta TA ve ÇK, ÇEK'e kıyasla daha iyi sonuç göstermiş ve TA ile ÇK arasında istatistiksel açıdan herhangi bir fark bulunamamıştır. Antil ve ark., (2006) substrat konsantrasyonunun, toprak neminin, organik madde türlerinin ve seviyelerinin, değişken $\mathrm{Pb}$ içeren toprakların üreaz enzim aktivitesi üzerindeki etkisini ölçmek için yaptıkları çalışmada, organik madde (kanatlı hayvan gübresi, çiftlik gübresi, atık çamur vb.) ilavesinin topraklarda üreaz enzim aktivitesini arttırdığını bildirmişlerdir. 


\section{Kampüs (Nötr)}

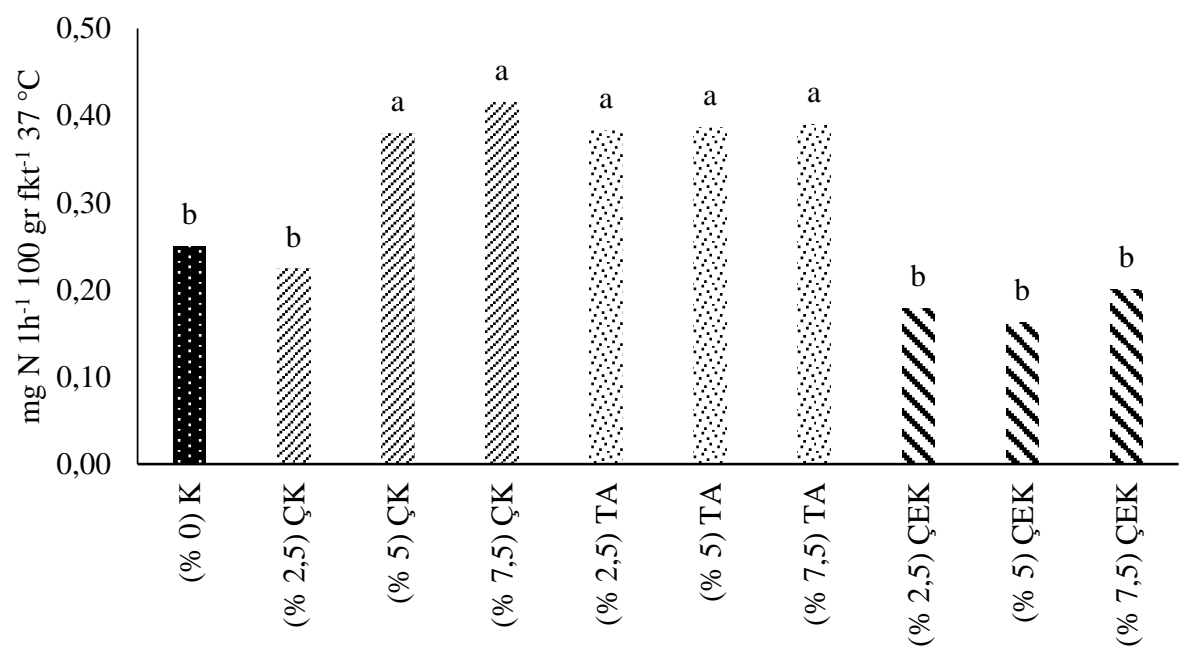

Şekil 2. Organik atık ve kompost uygulamalarının nötr toprakta üreaz enzim aktivitesine etkisi

Figure 2. Effect of organic waste and compost applications on urease enzyme activity in neutral soil

Alkalin reaksiyonlu toprakta üreaz enzim aktivitesinin 0.06-0.71 mg N $100 \mathrm{gr}^{-1}$ fkt $1 \mathrm{~h}^{-1} 37^{\circ} \mathrm{C}$ arasında değiştiği belirlenmiştir. Bu toprakta en yüksek üreaz enzim aktivitesi değeri TA uygulamaları sonrası belirlenmiştir. Yapılan uygulamalar içerisinde kontrol toprağına kıyasla ÇK \%2.5 ve ÇEK' in tüm doz uygulamalarında daha düşük üreaz enzim aktivitesi belirlenmiştir. Diğer uygulamalar sonrasında ise üreaz enzim aktivitesinin arttığı belirlenmiş̧ir. En yüksek üreaz enzim aktivitesi değeri ise TA $\% 7.5$ uygulaması sonrasında belirlenmiştir. Zhang ve ark., (2016), farklı organik materyal uyguladıkları tuzlu sahil topraklarında, organik materyallerin toprak üreaz enzim aktivitesi ve topraktaki mevcut azot $(\mathrm{N})$ üzerine etkisini araştırmışlardır. Araştırma sonunda organik madde ilavesi ile toprakta üreaz enzim aktivitesinin belirgin bir şekilde arttığını bildirmişlerdir. Ayrıca benzer şekilde Wang ve ark., (2012), topraklara uygulanan organik gübrenin toprakta üreaz enzim aktivitesini yüksek derecede arttırdığını bildirmişlerdir.

Çetinkaya (Alkalin)

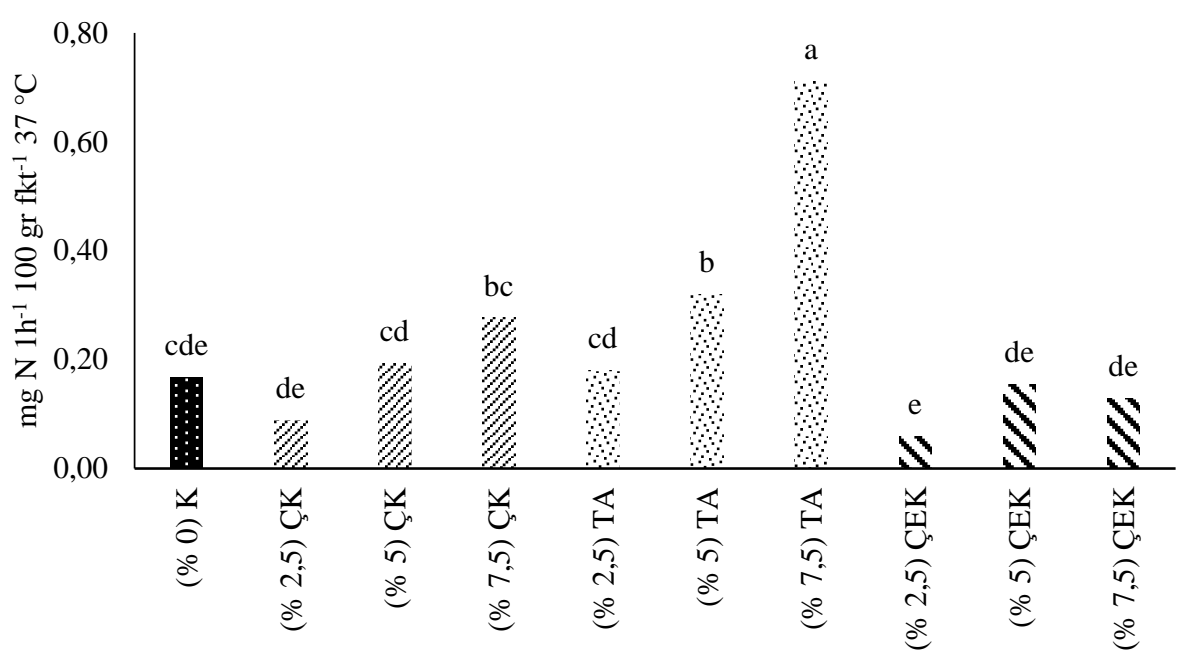

Şekil 3. Organik atık ve kompost uygulamalarının alkalin toprakta üreaz enzim aktivitesine etkisi

Figure 3. Effect of organic waste and compost applications on urease enzyme activity in alkaline soil 


\subsection{Korelasyon sonuçları}

Elde edilen bulgulara göre toprakta üreaz enzim aktivitesi ile bazı toprak özellikleri arasında yakın ilişkiler belirlenmiştir. Çalışmada kullanılan 3 toprakta da üreaz enzim aktivitesi ile toprakların elektriksel iletkenliği ve organik madde kapsamı arasında istatiksel açıdan pozitif yönde önemli ilişkiler tespit edilmiştir. Benzer şekilde çoğu araştırıcı da toprakta organik madde ile üreaz enzim aktivitesi arasında pozitif ilişkiler olduğunu bildirmişlerdir (Gu ve ark., 2014; Zhao ve ark.,2014; Zhang ve ark., 2016). Çalışma sonunda Çetinkaya toprağının pH değeri ile üreaz enzim aktivitesi arasında negatif yönde önemli ilişki belirlenmişken diğer toprakların $\mathrm{pH}$ değerleri ile üreaz enzim aktiviteleri arasında herhangi bir ilişki belirlenememiştir. Bazı araştırmacılarda $\mathrm{pH}$ değeri ile üreaz enzim aktivitesi arasındaki ilişkinin değişim gösterebileceğini bildirmişlerdir (Pancholy ve Rice, 1973). Ayrıca üreaz enzim aktivitesi için optimum $\mathrm{pH}$ aralığı bazı araştırmacılar tarafindan 6.5-7.0 arasında olduğu belirtilirken, bazı araştırmacılar tarafindan ise 8.8-9.0 arasında olduğu belirtilmektedir (May ve Douglas, 1976;
Pettit ve ark., 1976; Kızılkaya ve ark., 1998). Yüksek pH değerindeki toprakta üreaz enzim aktivitesinin $\mathrm{CaCO}_{3}$ ile herhangi bir ilişkisinin olmadığı, nötr ve düşük pH'lı toprakta ise üreaz enzim aktivitesinin $\mathrm{CaCO}_{3}$ ile yakından ilişkili olduğu görülmektedir. Bulduğumuz sonucu destekler nitelikte Gasser (1964) ürenin hidrolizinin alkalin ve kireçli topraklarda daha yavaş olduğunu belirtmiştir. Liu ve ark., (2008) Çin'in Kuzeydoğusunda bulunan tarım arazilerinde mikrobiyal biyokütle ve enzim aktivitelerini araştırdıkları çalışmada üreaz, asit fosfotaz, ve dehidrogenaz aktivitelerinin toprak pH'sı ve elektriksel kondaktivite ile ilişkili olduğunu, üreaz aktivitesinin en yüksek değerlerine pH'nın 6.5-7.0 civarında olduğu topraklarda eriştiği tespit edilmiştir. Durmuş ve Kızılkaya (2016), benzer doğrultuda yürüttükleri araştırmada enzim aktivitesinin toprak reaksiyonundan etkilendiğini saptamışlardır. Organik ve geleneksel gübre uygulamalarının üreaz aktivitesi üzerindeki etkilerini irdeleyen Malero ve ark., (2006) ise organik gübreleme yapılan parsellerde daha yüksek bir üreaz aktivitesinin bulunduğunu, enzim aktivitelerinin birbiri ile ilişkili olduğunu ve yaz başı dönemlerde en yüksek seviyeye eriştiğini vurgulamışlardır.

Çizelge 4. Toprakların üreaz enzim aktivitesi ile bazı özellikleri arasındaki ilişkiler

Table 4. Relations between urease enzyme activity and some properties of soils

\begin{tabular}{ccccc}
\hline Toprak & $\mathrm{pH}$ & $\mathrm{EC}$ & $\mathrm{O} . \mathrm{M}$. & $\% \mathrm{CaCO}_{3}$ \\
\hline Tepecik & 0,213 & $0,662^{* *}$ & $0,363^{*}$ & $0,570^{* *}$ \\
Kampüs & 0,111 & $0,609^{* *}$ & $0,611^{* *}$ & $0,615^{* *}$ \\
Çetinkaya &,$- 751^{* *}$ &, $864^{* *}$ &, $834^{* *}$ &,- 077 \\
\hline
\end{tabular}

$(* *<0.01, *<0.05)$

\section{Sonuç}

Toprağa uygulanan organik materyaller toprak organik maddesinin kaynağını oluşturmaktadırlar ayrıca toprağın fiziksel yapısında meydana getirdikleri iyileşmelerden dolayı toprak düzenleyicisi olarak ta kullanılabilmektedirler. Toprağa ilave olan organik madde toprak içerisindeki mikroorganizma faaliyetlerini doğrudan ve dolaylı olarak etkilemektedir. Organik madde mikroorganizmalara karbon kaynağı olmasının yanı sıra toprakta iyi bir hava-su dengesi, strüktür oluşumu, agregatlaşmaya katkısı vb. etkileriyle toprak biyolojisine etki etmektedir. $\mathrm{Bu}$ sebeple topraktaki döngüler de bu durumdan olumlu etkilenmektedir. Yapılan bu çalışma sonunda organik madde girdisinin toprakta üreaz enzim aktivitesini artırdığı ve bu artışın organik maddenin uygulandığı toprağın $\mathrm{pH}$ değerine göre değişkenlik gösterdiği belirlenmiştir. Üreaz enzim aktivitesi üzerine toprağın $\mathrm{pH}$ değerinin yanı sıra toprağa uygulanan organik materyalin çeşidi ve hangi dozda uygulandığının da önemli olduğu anlaşılmıştır. Organik materyaller içerisinde en fazla etki tütün işleme atığ uygulamasında olmuştur ve bu durum tütün işleme atığının içerdiği yüksek azottan kaynaklı olabilir. Çeltik kavuzu kompostu organik materyaller içerisinde en dar $\mathrm{C}: \mathrm{N}$ oranına sahip organik materyal olmasına karşın üreaz enzim aktivitesi üzerine en az etkinin de bu uygulama sonrasında olduğu belirlenmiştir. Bu durumun çeltik kavuzu kompostunun düşük azot içeriğinden kaynaklı olabileceği düşünülmektedir.

Sonuç olarak, toprak canlı ve dinamik bir varlıktır. Güvenilir ve sağlıklı besin maddeleri için toprağın üretkenliğini ve canlılığını devam ettirmesi gerekmekte ve bunun için ise toprak organik maddesinin yönetimi büyük önem taşımaktadır. Topraklara organik madde ilavesi toprak canlılığı için temel bir unsurdur. Ancak organik madde yönetiminde toprağın kimyasal özellikleri, uygulanacak materyalin kimyasal yapısı ve uygulama dozu dikkat edilmesi gereken en önemli etkenlerin başında gelmektedir.

\section{Kaynaklar}

Antil, R. S., Mahata, M. K., Narwal, R. P. 2006. Effect of substrate concentration, soil moisture, and organic materials on urease activity of soil contaminated with lead, Archives of Agronomy and Soil Science, 52(1): 61-68.

Aona, M.A., Cabello, M.N., Sarena, D.E., Colaneri, A.C., Franco, M.G., Burgos, J.L., Cortassa, S. 2001. I. Spatio- 
temporal patterns of soil microbial and enzymaticactivities in an agricultural soil. Applied Soil Ecology 18: 239-254.

Arcak, S., Kütük, A.C., Haktanır, K., Çaycı, G. 1997. Çay atıklarının toprakta enzim aktivitesi ve nitrifikasyon üzerine etkileri. Pamukkale Üniversitesi Mühendislik Fakültesi Mühendislik Bilimleri Dergisi 3(1): 261-266.

Bandick, A.K., Dick, R.P. 1999. Field management effects on soil enzyme activities. Soil Biology and Biochemistry, 31: 1471-1479.

Baran, A., Çaycı, G., İnal, A. 1995. Farklı tarımsal atıkların bazı fiziksel ve kimyasal özellikleri. Pamukkale Üniversitesi Mühendislik Fakültesi Mühendislik Bilimleri Dergisi,1(23):169-172.

Bhavya, V.P., Anil Kumar, S., Shivanna, M., Shivakumar, K.M., Ashok A. 2017. Effect of organic matter on soil enzyme activity, organic carbon and microbial activity under different land use systems. International Journal of Chemical Studies 5(5): 301-305.

Bremner, J.M., Mulvaney, R.L. 1978. Urease activity in soils. In:Burns, R.G. (Ed.), Soil Enzymes. Academic Press, New York, pp. 149-196.

Campbell, C.A., Biederbeck, V.O., Zentner, R.P., Brandt, S.A., Schnitzer, M. 1992. Effect of crop rotations and rotation phase on characteristics of soil organic matter in a Dark Brown Chernozemic soil. Canadian Journal of Soil Science, 72(4): 403-416

Carney, K.M., Matson, P.A. 2005. Plant communities, soil microorganisms, and soil carbon cycling: Does altering the world belowground matter to ecosystem functioning? Ecosystems. 8 (8):928-940.

Chang E., Chung R., Tsai Y. 2007. Effect of different application rates of organic fertilizer on soil enzyme activity and microbial population, Soil Science and Plant Nutrition, 53(2): 132-140.

Çolakogu, H. 2004. Organo-mineral gübreler ve gübre kullanımı üzerine yeni yaklasımlar. 3. Ulusal Gübre Kongresi, 11-13 Ekim 2004 Tokat.

Dick, W.A., Tabatabai, M.A. 1992. Potential uses of soil enzymes. In: Meeting, F.B. (Ed.), Soil Microbial Ecology: Applications in Agricultural and Environmental Management. Marcel Dekker, New York, pp. 95-127.

Doğan, K., Sarıoglu, A., Şakar, E., Karanlık, S. 2018. Zeytin karasuyu, 1sıl işlem görmüş solucan gübresi ve çiftlik gübresi uygulamalarının toprak mikrobiyal aktivite değişimlerine etkisi. Süleyman Demirel Üniversitesi Ziraat Fakültesi Dergisi 1. Uluslararası Tarımsal Yapılar ve Sulama Kongresi Özel Sayısı:151-159.

Durmuş, M., Kızılkaya, R. 2016. Kombu çayı (Kombucha) ve kombu çayı üretim artığı karışı mikroorganizma kültürünün buğday bitkisinin verimi ile toprakların dehidrogenaz ve katalaz aktivitesi üzerine etkisi. Toprak Bilimi ve Bitki Besleme Dergisi, 4(2): 76-82.

Düzgüneş, O. K. 1987. Araştırma ve deneme metotları. Ankara Üniversitesi, Ziraat Fakültesi Yayınları, 381, Ankara.

Eraslan, F., İnal, A., Güneş, A., Erdal, İ., Coşkan, A. 2010. Türkiye'de kimyasal gübre üretim ve tüketim durumu, sorunlar, çözüm önerileri ve yenilikler, TMMOB Ziraat Mühendisleri Odası, Ziraat Mühendisliği VII. Teknik Kongresi, 11-15 Ocak 2010, Ankara.

FAO, 2016. Fertilizer requirements in 2015 and 2030, pp. 25, Roma.

Ferreras, L., Gomez, E., Toresani, S., Firpo, I., Rotondo, R. 2006. Effect of organic amendments on some physical, chemical and biological properties in a horticultural soil. Bioresource Technology 97; 635-640.
Gasser, J.K.R. 1964. Urea as a fertilizer. Soils Fert. 27:175-180.

Gu, S., Wang, R., Geng, Z., Wang, J., Zhou, L., Wei, Z. 2014. "Effects of bio-organic fertilizer on enzyme activity and humus composition in saline soil.” Journal of Soil and Water Conservation 28: 147-151.

Hackl, E., Zechmeister-Boltenstern, S., Bodrossy, L., Sessitsch, A. 2004. Comparison of diversities and compositions of bacterial populations inhabiting natural forest soils. Appl Environ Microbiol. 70(9): 5057-5065.

Hoffmann, Gg., Teicher, K. 1961. Ein Kolorimetrisches Verfahren zur Bestimmung der Urease Aktivitat in Böden. Zeitschrift für Pflanzenernährung und Bodenkunde, 91(140): 55-63.

Kacar, B., İnal, A. 2008. Bitki analizleri, Nobel Yayın No:1241, Fen Bilimleri:63.

Karaca, A., Naseby, D.C., Lynch, J.M., 2002. Effect of cadmium contamination with sewage sludge and phosphate fertilizer amendments on soil enzyme activities, microbial structure and available cadmium. Biology and Fertililty of Soils, 35: 428-434.

Kızılkaya, R., Arcak, S., Horuz, A., Karaca, A. 1998. Çeltik tarımı yapılan toprakların enzim aktiviteleri üzerine toprak özelliklerinin etkisi. Pamukkale Üniversitesi Mühendislik Bilimleri Dergisi. 4(3): 797-804.

Kızılkaya, R., Heps̨en, S. 2004. Effect of biosolid amendment on enzyme activities in earthworm (Lumbricus terrestris) casts. Journal of Plant Nutrition and Soil Science 167(2): 202-208.

Kurt, S. 2016. Biyokömür ve vermikompostun misır bitkisinin (zea mays l.) kök bölgesindeki enzim aktiviteleri üzerine etkisi. Ordu Üniversitesi Fen Bilimleri Enstitüsü Toprak Bölümü ve Bitki Besleme ABD, Yüksek Lisans Tezi, 45s.

Liu, K.L., Lai, C.M., Helen, W. 2002. Soil enzyme activities as indicators agricultural soil quality. Symposium no: 32, s: 1386, Thailand.

Liu, X. M., Li, Q., Liang, W. J., Jiang, Y. 2008. Distribution of Soil Enzyme Activities and Microbial Biomass Along a Latitudinal Gradient in Farmlands of Songliao Plain. Northeast China18(4): 431-440.

Marinari, S., Mancinelli, R., Campiglia E., Grego, S. 2006. Chemical and biological indicators of soil quality in organic and conventional farming systems in Central Italy. Ecological Indicators 6:701-711.

May, P.B., Douglas, L.A. 1976. Assay for soil urease activity. Plant Soil 45: 301-305.

Mengel, K. 1991. Available nitrogen in soils and its determination by the Nmin-method and by electroultrafiltration (EUF), Fert. Res. 28, 251-262.

Özdemir, N., Gülser, C., Kızılkaya, R., Kop Durmuş, Ö.T., Ekberli, İ. Effects of organic conditioner applications on dehydrogenase activity in soils having different $\mathrm{pH}$ levels. Ziraat Fakültesi Dergisi, Atatürk Üniversitesi, 49(1): 21-27.

Pancholy, S., Rice, E. 1973. Soil enzymes in relation to old field succession : amylasei cellulase, intervase, dehydrogenase and urease. Soil Sci. Soc. Am. Proc. 37: 47-50.

Pettit, N.M., Smith, A.R.J., Frredman, R.B., Burns R.G. 1976. Soil urease: activity, stability and kinetic properties. Soil Biol. Biochem. 8: 479-484.

Sawicka, A., Czekala, J., Wolna.A. 2004. Dynamics of the development of microorganisms in solls fertilised with sewage sludge and tobacco dust. Department of Agricultural Microbiology, ul. Wolynska 35: 60-637 Poznan, Poland.

Sirko, A., Brodzık, R. 2000. Review: plant ureases: roles and regulation, Acta Biochimica Polonica, 47, 1189-1195. 
Şahin G. 2016. Türkiye'de gübre kullanım durumu ve gübreleme konusunda yaşanan problemler, Tarım Ekonomisi Dergisi, 22(1): 19-32.

Tanaka, T., Kawase, M., Tan1, S. 2004, $\alpha$-Hydroxyketones as inhibitors of urease, Bioorganic \& Medicinal Chemistry, 12, 501-505.

Türkmen, C., Müftüoğlu, N., Kavdır, K. 2013. Değişik yöntemlerle 1slah edilen meralarda bazı toprak kalite özelliklerinin değişimi. Journal of Agricultural Sciences. 19:4.

Wang, Y., Lian, X.-J., Zhang, Y., Li, M., He, H., Wang, Z.-X. 2012 "Study on water-salt movement of coastal saline soil in tianjin.” Tianjin Agricultural Sciences 18: 95-97.

Zhang, T., Zhang, J., Wang, T., Tian, X., Ge, H., Ma, Y., Wang, K. 2016 Effects of organic matter on Leymus-chinensis germination, growth, and urease activity and available nitrogen in coastal saline soil, Toxicological \& Environmental Chemistry, 98(5-6): 623-629.

Zhao, J., Meng, Q., Zhou, L., Sun, Y., Ma. X. 2014. "Effect on soil enzyme activity and nutrient content in meadow alkali soil at long-term application of organic manure.” Soil and Fertilizer in China 2: 23-26.

Zimmermann, S., Frey, B. 2002. Soil respiration and microbial properties in an acidic forest soil: effects of wood ash. Soil Biology and Biochemistry, 34: 1727-1737. 